\title{
A Decade of Research on Coffee as an Anticarcinogenic Beverage
}

\author{
Ayelén D. Nigra $\mathbb{D}^{1},{ }^{1}$ Anderson J. Teodoro $\mathbb{D}^{2},{ }^{2}$ and Germán A. Gil $\mathbb{D}^{1}$ \\ ${ }^{1}$ Departamento de Química Biológica Ranwel Caputto, Facultad de Ciencias Químicas, Universidad Nacional de Córdoba- \\ CIQUIBIC, CONICET, Córdoba, Argentina \\ ${ }^{2}$ Universidade Federal do Estado do Rio de Janeiro, Laboratory of Functional Foods, Rio de Janeiro, CEP 22290-240, Brazil
}

Correspondence should be addressed to Anderson J. Teodoro; anderson.j.teodoro@unirio.br and Germán A. Gil; ggil@unc.edu.ar Received 16 July 2021; Revised 26 August 2021; Accepted 29 August 2021; Published 16 September 2021

Academic Editor: Alessandra Durazzo

Copyright (C) 2021 Ayelén D. Nigra et al. This is an open access article distributed under the Creative Commons Attribution License, which permits unrestricted use, distribution, and reproduction in any medium, provided the original work is properly cited.

\begin{abstract}
Coffee consumption has been investigated as a protective factor against cancer. Coffee is a complex beverage that contains more than 1000 described phytochemicals, which are responsible for its pleasant taste, aroma, and health-promoting properties. Many of these compounds have a potential therapeutic effect due to their antioxidant, anti-inflammatory, antifibrotic, and anticancer properties. The roasting process affects the phytochemical content, and undesirable compounds may be formed. In recent years, there have been contradictory publications regarding the effect of coffee drinking and cancer. Therefore, this study is aimed at evaluating the association of coffee consumption with the development of cancer. In PubMed, until July 2021, the terms "Coffee and cancer" resulted in about 2150 publications, and almost 50\% of them have been published in the last 10 years. In general, studies published in recent years have shown negative associations between coffee consumption and the risk or development of different types of cancer, including breast, prostate, oral, oral and pharyngeal, melanoma, skin and skin nonmelanoma, kidney, gastric, colorectal, endometrial, liver, leukemic and hepatocellular carcinoma, brain, and thyroid cancer, among others. In contrast, only a few publications demonstrated a double association between coffee consumption and bladder, pancreatic, and lung cancer. In this review, we summarize the in vitro and in vivo studies that accumulate epidemiological evidence showing a consistent inverse association between coffee consumption and cancer.
\end{abstract}

\section{Introduction}

Drinking coffee has often been discouraged, due to its association with the description of negative effects, mainly attributed to caffeine. Consumers' beliefs about the effects of coffee are strongly influenced by this idea: only $25 \%$, a relevant minority of consumers, think that drinking coffee could have beneficial effects on health [1]. A survey performed by the World Cancer Research Fund (WCRF) revealed that as many as $36 \%$ of health professionals thought drinking coffee increases the risk of cancer [2]. Despite the "bad reputation" that has been conferred on coffee for many years, it has been increasingly demonstrated that it offers numerous health benefits, ranging from reduced risk of several cancers to reduced risk of developing depression.

Coffee is widely consumed, ranking as one of the four most commonly consumed beverages in the world [3]. The generic name coffee covers about one hundred species of plants, cultivated in multiple countries with different types of weather conditions: Hawaii, Colombia, Jamaica, Ethiopia, Kenya, Brazil, Vietnam, and some African countries [4]. The coffee tree appertains to the Rubiaceae family, and there are more than 80 different species of the genus Coffea L. Globally, only two species are traded: Coffea arabica, accounting for $63 \%$ of the world production, and Coffea canephora, accounting for the rest of the world production [5]. As de Mejia et al. highlight, the species and the origin are only two of the factors that determine that we never drink two cups of coffee with the same chemical composition. Additionally, the final composition of coffee will depend on cultivation practices (traditional or organic), postharvest techniques (wet or dry), duration and conditions of storage, roasting degree (light, medium, or dark), kind of roasting process (standard or torrefaction), type of commercial coffee (roasted ground or instant), and grinding and brewing method (boiled, filtered, or espresso) [6]. 
The consumption of coffee may have a substantial effect on public health. In 2017, two large reviews based on metaanalyzes were published, which established that coffee consumption was more often associated with benefit than harm, a probable decrease in the risk of breast, colorectal, colon, endometrial, and prostate cancer; cardiovascular disease and mortality; Parkinson's disease; and type 2 diabetes [7, 8]. Then, it is no surprise that coffee motivates the interest of researchers and clinicians [9]. In PubMed, until April 2021, the search for the term "coffee" resulted in around 17,200 publications, including 1,430 reviews, 800 clinical trials, and 260 meta-analyses. However, the impact of coffee intake on chronic diseases, including cancer, has been a matter of debate in the last two decades. Accordingly, the search performed by combining both terms, "coffee and cancer", resulted in about 2,150 publications, and almost $50 \%$ of them have been published in the last 10 years.

In this work, we present an update on the last decade of research related to coffee and its anticancer activity. For this purpose, a broad approach was used, as follows: (1) analysis of the main coffee compounds and their modifications by the roasting process, (2) review of the bioactivity of coffee extracts by in vitro assays, (3) analysis of the antioxidant activity of coffee and its components, and (4) data collection of large observational human studies.

1.1. Search Strategy. We searched on the PubMed database for basic and meta-analysis articles published from 2010 to June 2021. The search included the following relevant terms: "coffee" paired with "cancer," "roasting," "green," "dark," "bioactive," "composition," "in vitro," "cell line," "antioxidant," "breast," "leukemic," "oral," "oral and pharyngeal," "gastric," "non-melanoma skin," "melanoma," "endometrial," "hepatocellular," “prostate," “esophageal," “ovarian,” "colorectal," "liver," "brain," "glioma," "thyroid," "bladder," "pancreatic," "laryngeal," "lung," “caffeine," "polyphenol," "Trigonelline," "chlorogenic acid," "cafestol," "kahweol," "caffeic acid," "melanoidin," "nicotinic acid," "flavonoid," and "N-methylpyridinium."

No language restrictions were imposed. When available, priority was given to the conclusions of meta-analyses and systematic reviews. Within these studies, we selected those that reported statistically significant associations in their analyses, whether positive or negative.

\section{The Main Bioactive Compounds of Coffee and Their Modifications by the Roasting Process}

The traditional recommendation to reduce the consumption of coffee as a beverage or not to drink it at all because of a global risk profile has progressively given rise to a less negative view due to its better-known phytochemistry [10]. The knowledge that coffee and caffeine are not equivalent has increased the interest in discovering whether other components of coffee might contribute to the protective action in the human body [9]. Coffee is a complex beverage containing more than 1000 described phytochemicals responsible for its pleasant flavor, aroma, and health promoters $[1,6$,
10]. Many of these compounds have therapeutic potential antioxidant, anti-inflammatory, antifibrotic, and anticancer effects.

As a consequence of roasting, profound changes occur in the chemical composition, which leads to the transformation of natural substances present in green beans into compounds derived from the Maillard reaction [4]. Table 1 shows the main compounds of green coffee, i.e., coffee beans before roasting, and the appearance of or increase in specific components in black coffee beans. This well-known roasting process involves the caramelization of carbohydrates and the pyrolysis of organic compounds. Here, we detail the main phytochemicals belonging to groups of sugars and sugar metabolites, protein and amino acids, fatty acids, chlorogenic acids (CGAs), organic acids, and other compounds.

"Bioactive compounds" are extra nutritional constituents that typically occur in small quantities in foods and have a positive effect on human health. These are also referred to as nutraceuticals, a term that reflects their existence in the human diet and their biological activity. They consist of a wide range of chemical compounds with different structures, physiological activities, and molecular mass between 200 and $1000 \mathrm{Da}$ [11]. Green coffee beans have been shown to have high levels of bioactive compounds, but even after the roasting process and exposure to hot water, dark coffee maintains and develops numerous new phytochemicals that are beneficial to consumers' health [12].

As highlighted in Table 1, during the roasting process, the concentration of some nutraceutical compounds, such as 5-CQA, 3,4-diCQA, 3,5-diCQA, phenolic acid, trigonelline, polyphenolic, cafestol, and kahweol, decreases while others are formed, such as melanoidins, chlorogenic lactones, acid gallic, acid nicotinic, caffeic acid, flavonoids, and N-methylpyridinium (all of them marked in bold). This delicate balance between the formation and decomposition of bioactive compounds allows the biological effects of dark roasted coffee to be found in experimental models. Sometimes, these effects are higher in dark than lighter roasted coffee, despite the antioxidant content in dark coffee is lower [1]. In fact, Priftis et al. reported that in eight out of 13 coffee varieties, toasted coffee increased the free radical scavenging activity [13].

The five most abundant bioactive constituents in green coffee are (I) caffeine, which has been positioned by numerous studies as a protective agent for cell membranes against oxidative damage, with anticancer activity $[4,14,15]$ and anti-inflammatory effects [16]; (II) polyphenols, which can cause a variety of important bioactivities with beneficial effects on human health [4]; (III) trigonelline, which has hypoglycemic, neuroprotective, antitumor (anti-invasive), antibacterial, and antiviral activities [3, 4, 17]; (IV) chlorogenic acids (CGAs), the most important class of polyphenols, which can be grouped into caffeoylquinic acids (CQA), feruloylquinic acids (FQA), and di-caffeoylquinic acids (diCQA), all of which are known to have powerful antioxidant, anticancer, anti-inflammatory, antibacterial, antipyretic, hepatoprotective, and neuroprotective effects and can help prevent retinal degeneration, obesity, and hypertension $[4,12,18,19]$; and (V) cafestol and kahweol, main coffee 
TABle 1: Compounds that increase or decrease during the coffee bean roasting process. The left column shows the most abundant compounds in green coffee that are lost during the roasting process, while the right column shows those that appear during the roasting process. The known bioactive compounds are marked in bold.

Coffee bean roasting process

\begin{tabular}{|c|c|c|}
\hline $\begin{array}{l}\text { Polysaccharide sugars and sugar } \\
\text { metabolites }\end{array}$ & $\begin{array}{l}\text { Sucrose }[3,19,63-66], \text { fructose } \\
{[4,19,66], \text { arabinos, galactose, }} \\
\text { glucose }[4,66], \text { mannose, } \\
\text { manitol, xylose, ribose }[4]\end{array}$ & Hydroxymethyl-furfural $[3,63,64]$ \\
\hline $\begin{array}{l}\text { Proteins and } \\
\text { amino acids }\end{array}$ & $\begin{array}{l}\text { Asparagine }[4,19,64] \\
\text { proline, glutamine, histidine, } \\
\text { leucine, phenylalanine }[19], \\
\text { alanine }[4,64]\end{array}$ & Protein [66] \\
\hline Lipids Fatty acids & $\begin{array}{l}\text { Palmitic, stearic }[4,33] \text {, arachidic, } \\
\text { linolenic, oleic, arachidic }[4,33]\end{array}$ & (PUFA) n-6, MUFA+PUFA [33] \\
\hline $\begin{array}{l}\text { Polyphenols Chlorogenic acid } \\
\text { (CGA) }\end{array}$ & $\begin{array}{c}\text { 1-FQA [66], 4-CoQA [66], } \\
\text { 4-FQA [66, 67], 3-CQA, } \\
\text { 5-CQA, 4-CQA 4, [64, 66, 67], } \\
\text { 5-FQA [66, 67], } \\
\text { 4,5-diCQA [67], 3,4-diCQA, } \\
\text { 3,5-diCQA [66, 67] }\end{array}$ & $\begin{array}{l}\text { 3-CoQA, 3-FQA, 5-CoQA [66], } \\
\text { chlorogenic lactones [4] }\end{array}$ \\
\hline Organic acids & $\begin{array}{l}\text { Citric, GABA, malic [64], } \\
\text { quinic }[4,64] \text {, phenolic }[4,14,19]\end{array}$ & $\begin{array}{c}\text { Gallic [12, 63], caffeic }[4,12,63] \text {, } \\
\text { acetic [63], formic, lactic [63, 64], syllo-quinic [64], } \\
\text { nicotinic (Niacin and Vitamin B3) }[3,4,64]\end{array}$ \\
\hline Other compounds & $\begin{array}{c}\text { Caffeine }[3,4,19,64,66] \\
\text { trigonelline }[3,4,64], \\
\text { polyphenolic content }[13,48] \text {, choline } \\
{[3,64] \text {, cafestol, }} \\
\text { kahweol [68], fluoride [42] }\end{array}$ & $\begin{array}{c}\gamma \text {-Quinide }[4,64] \text {, flavonoids [69], } \\
\text { N-methylpyridinium [3], alkyl esters, shikimoyl esters [4], } \\
\text { melanoidins }[3,4,13]\end{array}$ \\
\hline
\end{tabular}

diterpenes that have demonstrated anti-inflammatory, hepatoprotective, anticancer (tumor cell-inducing apoptosis and antiangiogenesis), antidiabetic, and antiosteoclastogenesis activities [20,21].

In contrast, the main bioactive molecules in roasted coffee are (I) caffeic acid, with biological activities such as antitumor, antioxidation, anti-inflammatory, and immune regulation properties [4, 12, 17]; (II) melanoidins, whose nutritional antiradical, antioxidant, chelating, antimicrobial, antimutagenic, anticariogenic, antihypertensive, anti-inflammatory, and antiglycative properties have been described [22, 23]; (III) nicotinic acid (Niacin or Vitamin B3), which plays a role in DNA repair (interacting with PARP), has tumor suppressive effects, and inhibits cancer cell invasion (blocking epithelial-mesenchymal transition) [24, 25]; (IV) flavonoids, which exhibit a great diversity of biological activities, such as antioxidant, antiaging, anti-inflammatory, immunomodulation, cardioprotective, antibacterial, antiviral, antiparasitic, antihypertensive, antiulcerogenic, antidiabetic, and hepatoprotective properties, as well as prevention against cancer (including carcinogen inactivation, antiproliferation, cell-cycle arrest, induction of apoptosis, inhibition of angiogenesis, antioxidation, and reversal of multidrug resistance or a combination of these mechanisms)
$[26,27]$; and $(V) N$-methylpyridinium, identified as inducers of antioxidant response element pathway [28].

In summary, although in vitro and in vivo studies using individual components of coffee revealed multiple biological activities, the physiological properties of whole coffee will likely differ because coffee is a complex, nonstandardized beverage. Therefore, it is a variable mixture of hundreds of compounds, and its bioactivity may be influenced by possible matrix, synergistic, and/or antagonist effects. Additionally, only a small percentage of the ingested compounds may enter the circulatory system and reach the tissues, and very little of the absorbed material may retain the original structure present in the beverage [4]. For these reasons, it is worth pointing out that the prevention of various diseases derived from coffee consumption is usually the joint action of multiple components, and sometimes the synergistic effect of various types of compounds is much better than the activity of single compounds [29].

\section{Bioactivity of Coffee Extracts, Evidence Provided by In Vitro Studies}

Despite all the bioactivities described above for individual compounds isolated from coffee, in this work, we highlight 
TABLe 2: In vitro studies in cell lines. Effects of different types of coffee on a broad spectrum of human cancer cell lines.

\begin{tabular}{|c|c|c|c|c|c|c|}
\hline $\begin{array}{l}\text { Author, date } \\
\text { (year) }\end{array}$ & Cell lines & Cancer type & Coffee variety & Coffee type & $\mathrm{IC}_{50}$ & Effects \\
\hline Pounis, 2017 [32] & $\begin{array}{c}\text { PC-3 } \\
\text { DU145 }\end{array}$ & Prostate & Uninformed & Roasted & Uninformed & Antiproliferative \\
\hline $\begin{array}{l}\text { Montenegro, } \\
2021[5,31]\end{array}$ & $\begin{array}{l}\text { PC-3 } \\
\text { DU145 }\end{array}$ & Prostate & Arabica Brazil & $\begin{array}{l}\text { Roasted } \\
\text { Green }\end{array}$ & $1-5 \mathrm{mg} / \mathrm{mL}$ & $\begin{array}{c}\text { Cell-cycle arrest } \\
\text { Antiproliferative, apoptosis, } \\
\text { high antioxidant capacity }\end{array}$ \\
\hline $\begin{array}{l}\text { Palmioli, } \\
2017[70]\end{array}$ & MDA-MB-231 & Breast & $\begin{array}{l}\text { Arabica (Brazil, } \\
\text { Burundi } \\
\text { and Colombia) } \\
\text { Robusta (Uganda, } \\
\text { Vietnam, and } \\
\text { Tanzania) }\end{array}$ & $\begin{array}{l}\text { Roasted } \\
\text { Green }\end{array}$ & $\begin{array}{c}121 \pm 10 \mathrm{ng} / \mu \mathrm{l} \\
72 \pm 7 \\
-315 \pm 17 \mathrm{ng} / \mu \mathrm{l}\end{array}$ & Antiproliferative \\
\hline $\begin{array}{l}\text { Amigo-Benavent, } \\
2017 \text { [18] }\end{array}$ & $\begin{array}{l}\text { OE-33 } \\
\text { T24 } \\
\text { A549 }\end{array}$ & $\begin{array}{l}\text { Esophageal } \\
\text { Urinary } \\
\text { bladder } \\
\text { Lung }\end{array}$ & $\begin{array}{l}\text { Coffea arabica } L . \\
\text { (Colombia) }\end{array}$ & Green & $01-1 \mathrm{mg} / \mathrm{mL}$ & Antiproliferative \\
\hline Bauer, 2018 [19] & DU-145 & Prostate & $\begin{array}{l}\text { Coffea canephora } \\
\text { var. } \\
\text { Robusta (Brazil) }\end{array}$ & $\begin{array}{l}\text { Dark, } \\
\text { medium, } \\
\text { light, green }\end{array}$ & Uninformed & $\begin{array}{l}\text { Antiproliferative, } \\
\text { induced apoptosis }\end{array}$ \\
\hline Mojica, 2018 [12] & $\begin{array}{l}\text { HT-29 } \\
\text { SCC-25 }\end{array}$ & $\begin{array}{l}\text { Colon } \\
\text { Oral }\end{array}$ & Columbia Supremo & $\begin{array}{l}\text { Geen, } \\
\text { cinnamon, } \\
\text { city, full } \\
\text { city, } \\
\text { full city } \\
\text { plus }\end{array}$ & Uninformed & $\begin{array}{l}\text { Antiproliferative, } \\
\text { antioxidant activity }\end{array}$ \\
\hline $\begin{array}{l}\text { Funakoshi-Tago } \\
2020[71]\end{array}$ & MCF-7 & Breast & $\begin{array}{l}\text { Columbia Arabica } \\
\text { Japan }\end{array}$ & $\begin{array}{l}\text { Roasted } \\
\text { coffee }\end{array}$ & $2.5,5 \mathrm{v} / \mathrm{v} \%$ & $\begin{array}{c}\text { Cell-cycle arrest, apoptosis, } \\
\text { enhances tamoxifen } \\
\text { proapoptotic activity. }\end{array}$ \\
\hline Makino 2021 [35] & ACHN Caki-1 & Kidney & $\begin{array}{c}\text { Arabica or Robusta } \\
\text { Coffee } \\
\text { Japan }\end{array}$ & Roasted & Uninformed & $\begin{array}{c}\text { Antiproliferative, } \\
\text { antimigratory, apoptosis }\end{array}$ \\
\hline Oleaga, 2012 [36] & $\begin{array}{l}\text { HT29 } \\
\text { MCF-7 }\end{array}$ & $\begin{array}{l}\text { Colon } \\
\text { Breast }\end{array}$ & $\begin{array}{l}\text { Instant caffeinated } \\
\text { coffee }\end{array}$ & & Uninformed & $\begin{array}{l}\text { Cyclin D1, STAT5B, and } \\
\text { ATF-2 downregulated }\end{array}$ \\
\hline Nigra, 2021 [30] & $\begin{array}{c}\text { MDAMB-231 } \\
\text { MCF-7 } \\
\text { HCT116 } \\
\text { U2OS } \\
\text { T98G }\end{array}$ & $\begin{array}{c}\text { Breast } \\
\text { Colon } \\
\text { Osteosarcoma } \\
\text { Glioblastoma }\end{array}$ & $\begin{array}{l}\text { Coffea canephora } \\
\text { var. } \\
\text { Robusta Brazil }\end{array}$ & $\begin{array}{l}\text { Roasted } \\
\text { green }\end{array}$ & $1 \mathrm{mg} / \mathrm{mL}$ & $\begin{array}{l}\text { Antiproliferative, cell-cycle } \\
\text { arrest, induced apoptosis, } \\
\text { mitochondrial dysfunction }\end{array}$ \\
\hline
\end{tabular}

the studies that consider whole -/coffee, because it has been shown that after a person drinks 2-3 cups of coffee, many components are metabolized (thus changing their original structures) or only reach transient and very low plasma concentrations $[4,12]$. Additionally, it has not been possible to attribute the diverse and extensive bioactive capabilities of coffee to any pure compound.

In the last decade, numerous research groups have focused on the effect of coffee on tumors by conducting in vitro studies, to understand the bioactivities of this beverage in greater depth. Table 2 presents many of these in vitro studies, which have addressed a great diversity of cancer types, coffee varieties, degrees of roasting [5, 19, 30, 31], and diverse effects including cell-cycle arrest, antiproliferative effects, and antiapoptotic and high antioxidant activities.

Remarkably, most of the investigations report a wide range of coffee effects on cancer cells. For example, studies on breast cancer cells focused on antiproliferative and anti- oxidant effects, cell-cycle arrest, induced apoptosis, regulation of gene expression, modulation of enzyme activity, and enhanced efficiency of cancer treatments [30, 32-34]. Studies on prostate cancer cells reported antiproliferative effects, cell-cycle arrest, apoptosis, and high antioxidant capacity [5, 19, 31, 32]. Research on kidney cancer cells found antiproliferative and antimigratory effects, EMT downregulation, and gene downregulation [35]. Furthermore, antiproliferative effects were reported in esophageal, urinary, bladder, lung, colon, oral, osteosarcoma, and glioblastoma cancer cells $[12,18,30,36]$.

Additionally, as Samoggia and Riedel and Montenegro et al. pointed out, intake of green coffee-based beverages has become popular in recent years due to the belief in their beneficial antioxidant properties $[1,31]$. Some researchers have observed that green coffee treatments have antiproliferative activity, though not as powerful as that of roasted coffee treatments [12]. However, further cell experiments 
should be conducted to evaluate the deep molecular mechanisms and pharmacokinetics involved in the effects observed. The bioavailability and bioaccessibility of extracts should be investigated to determine the quantity of coffee required to achieve such effects, due to possible losses during digestion, absorption, and metabolization by the gut microbiota. Toxicity assays should be performed to ensure safety. In addition, in vivo and clinical tests would be required to recommend the consumption of different coffee types to help protect against cancer.

\section{Antioxidant Properties of Coffee}

As highlighted in the previous sections, among the main biological activities of the beverage and its components, the antioxidant activity was made evident in numerous investigations, both in chemical tests and different tumor cell cultures.

When, in aerobic life and our metabolism, the electron flow becomes uncoupled (transfer of unpaired single electrons), free radicals are continuously produced by the body's normal use of oxygen such as respiration. Oxygen-centered free radicals or ROS radicals are superoxide, hydroxyl, peroxyl, alkoxyl, hydroxyl radical, nitric oxide, and lipid hydroperoxides, while ROS nonradicals are singlet oxygen, hydrogen peroxide, and hypochlorous acid. Therefore, these intermediates, also called oxidants or prooxidants, can easily initiate the peroxidation of membrane lipids [37]. The imbalance towards high ROS concentration could result in oxidative damage to critical cellular biopolymers (proteins, lipids, and nucleic acids), especially if the free radicals are produced and accumulate unchecked for a prolonged period. The sustained oxidative damage of these biological macromolecules is linked to the development of chronic diseases like cancer.[38]. The reason why antioxidants are thought to be beneficial to our health is that ROS have been shown to be involved in many disease processes, including cancer [39].

In terms of food, an antioxidant has been defined as any substance that, when present at lower concentrations than those of an oxidizable substrate, significantly delays or inhibits the oxidation of the substrate. In recent years, there has been great interest in identifying alternative natural and safe sources of food antioxidants, especially those of plant origin. Nowadays, there is a growing interest in substances exhibiting antioxidant properties, which are supplied to human organisms as food components or as specific preventive pharmaceuticals [37]. The possibility of complementing the body's natural antioxidant defense system with exogenous antioxidants has continued to receive significant research attention as a result of their potential for wide applications [38].

In this sense, the antioxidant activity of coffee and of many of its components has been demonstrated [29, 40-43]. Additionally, recent studies have shown that coffee components can trigger tissue antioxidant gene expression and protect against gastrointestinal oxidative stress [44].

Recent studies conclude that coffee infusions significantly extend the chronological lifespan of the Saccharomy- ces cerevisiae yeast cells by protecting cells against reactive oxygen species, double DNA-strand break, and the decrease in metabolic activity [45]. However, the bibliography currently gives contradictory information as to whether slightly roasted or dark coffee generates greater antioxidant activity. Water extracts from green coffee are characterized by significant antioxidant properties and a high capacity to reduce transition metal ions because it contains many polyphenolic compounds that oxidize in the potential range tested [19, 46]. Jung et al. found that the cellular antioxidant activity of coffee extracts (in AML-12 and RAW 264.7 cells) has physiological antioxidant and anti-inflammatory activities, and that these effects are negatively correlated with roasting levels in the cell models [47]. Bobková et al. also support this theory, since they established that total antioxidant capacity reached the highest values in light roasted coffee, and the roasting process affected both the oxidative activity and the polyphenolic content [48]. Schouten et al. confirmed that acrylamide levels and antioxidant activity reached a maximum in the first coffee roasting degrees and then decreased as the heating process continued, both in Arabica and Robusta samples [49]. Wolska et al. showed that the method of brewing Arabica coffee and green coffee (simple infusion, espresso maker, French press, overflow espresso, or Turkish coffee) significantly affected the antioxidant potential of infusions [42]. In other research, antioxidant activity significantly rose with the degree of roasting, where strongly roasted coffee had higher activity than lightly roasted coffee [50].

As mentioned above, many coffee micronutrients are considered bioactive due to their high antioxidant capacity. Investigations have revealed that crude caffeine possesses hydrophilic antioxidant activity (145 ?mol Trolox equivalent (TE)/g) and lipophilic antioxidant activity (66 ?mol TE/g) [51], and its administration has led to the inhibition of the cyclooxygenase-2 enzyme [40]. The antioxidant activities of CGA exhibited protection against oxidative damage of macromolecules such as DNA, lipids, and proteins. When administered to mice under scopolamine-induced amnesia, CGA showed a neuroprotective function via the inhibition of acetylcholinesterase [40]. Coffee melanoidins, compounds formed during coffee roasting, have also been demonstrated as potential food ingredients due to their antioxidant properties. The antioxidant activity of these compounds, evaluated in vitro, was $725-750 \mu \mathrm{mol}$ Trolox/g, and it was tripled by the addition of sugar during coffee roasting, namely, torrefaction, known to increase the content of melanoidins [41]. Czachor et al. provide strong evidence that coffee flavonoids are responsible for scavenging free radicals and leading to longevity in yeast lacking Sod1, Sod2, and Rad52 proteins [45].

\section{Have We Been Drinking a Medicine Daily for Hundreds of Years without Knowing It?}

In recent years, the number of consistent epidemiological evidence of coffee and cancer has accumulated but due to similar methodological limitations, it is sometimes unsatisfactory. Therefore, interest has focused on meta-analyses or 
TABLE 3: Coffee consumption and cancer risk. 78 meta-analyses, cohort, or prospective studies, published between 2010 and 2021 , which reported some type of significant association between coffee consumption and different cancer types, were analyzed. Italic rows: studies that report a negative association between coffee and cancer risk; bold rows: studies that report a positive association between coffee and cancer risk. Abbreviations: Pt: participants; Cn: control; Cn: cancer cases; c/d: cups/day.

\begin{tabular}{|c|c|c|c|c|}
\hline First author, date & Type of cancer & Study group & $\begin{array}{l}\text { Date of } \\
\text { completion of } \\
\text { included data }\end{array}$ & Observed effect on coffee consumption \\
\hline $\mathrm{Yu}, 2011[72]$ & & $\begin{array}{l}40 \text { prospective cohort studies } \\
(2,179,126 \mathrm{Pt} \text { and } 34,177 \mathrm{Cc})\end{array}$ & March 2010 & $\begin{array}{l}\text { Meta-analysis showed coffee } \\
\text { drinking had an inverse } \\
\text { association with cancer. }\end{array}$ \\
\hline $\mathrm{Li}, 2013$ [73] & & $\begin{array}{l}16 \text { cohort and } 10 \text { case-control } \\
\text { studies }(49,497 \mathrm{Cc})\end{array}$ & July 2012 & $\begin{array}{c}\text { An inverse association was } \\
\text { observed in } \mathrm{ER}^{-} \text {negative subgroup. }\end{array}$ \\
\hline Jiang, 2013 [74] & & $\begin{array}{c}37 \text { articles }(966,263 \\
\text { Pt and 59,018 Cc) }\end{array}$ & $\begin{array}{c}\text { December } \\
2012\end{array}$ & $\begin{array}{l}\text { A strong and significant } \\
\text { association with cancer risk } \\
\text { was found for BRCA } 1 \text { mutation } \\
\text { carriers. The risk of breast } \\
\text { cancer decreased by } \\
2 \% \text { for every } 2 \text { days. }\end{array}$ \\
\hline Lowcock, 2013 [52] & & $\begin{array}{c}1 \text { cohort study }(3,427 \mathrm{Cn} \\
\text { and } 3,062 \mathrm{Cc})\end{array}$ & $2002-2003$ & $\begin{array}{l}\text { High coffee consumption, } \\
\text { but not total caffeine, } \\
\text { may be associated with } \\
\text { reduced risk of ER }{ }^{-} \text {and } \\
\text { postmenopausal cancers. }\end{array}$ \\
\hline Simonsson, 2013 [75] & Breast & 1 preoperative study $(634 \mathrm{Pt})$ & $2002-2008$ & $\begin{array}{l}\text { Tamoxifen-treated patients } \\
\text { with } \mathrm{ER}^{+} \text {tumors who consumed } \\
2 \text { or more c/d had significantly } \\
\text { decreased risk for early events. }\end{array}$ \\
\hline Rosendahl, 2015 [76] & & $\begin{array}{l}1 \text { cohort (1,090 Pt with invasive } \\
\text { primary cancer })\end{array}$ & $2002-2012$ & $\begin{array}{l}\text { A moderate }(2-4 \mathrm{c} / \mathrm{d}) \text { to } \\
\text { high }(\geq 5 \mathrm{c} / \mathrm{d}) \text { coffee intake } \\
\text { was associated with smaller } \\
\text { invasive primary tumors } \\
\text { and a lower proportion } \\
\text { of } \mathrm{ER}^{+} \text {tumors. }\end{array}$ \\
\hline Lafranconi, 2018 [77] & & 21 prospective studies & March 2017 & $\begin{array}{c}\text { Coffee intake was associated } \\
\text { with a } 10 \% \text { reduction } \\
\text { in postmenopausal cancer risk. }\end{array}$ \\
\hline Sánchez-Quesada, 2020 [78] & & 1 cohort study $(10,812 \mathrm{Pt})$ & Uninformed & $\begin{array}{l}\text { Among postmenopausal women, } \\
\text { more than } 1 \mathrm{c} / \mathrm{d} \text { of coffee } \\
\text { was associated with a } \\
\text { lower incidence of cancer. }\end{array}$ \\
\hline
\end{tabular}

\begin{tabular}{|c|c|c|c|c|}
\hline $\mathrm{Yu}, 2011[72]$ & Leukemic & $\begin{array}{c}40 \text { prospective cohort studies } \\
(2,179,126 \mathrm{Pt} \\
\text { and } 34,177 \mathrm{Cc})\end{array}$ & March 2010 & $\begin{array}{l}\text { It confirmed that coffee consumption is } \\
\text { associated with a reduced risk of cancer. }\end{array}$ \\
\hline Zhang, 2015 [79] & & $\begin{array}{l}12 \text { studies }(1,872,231 \mathrm{Pt} \\
\text { and } 4,037 \mathrm{Cc})\end{array}$ & March 2015 & $\begin{array}{l}\text { Higher consumption might } \\
\text { reduce the risk of cancer, especially in } \\
\text { Europe. }\end{array}$ \\
\hline $\mathrm{Li}, 2016[80]$ & & $\begin{array}{c}11 \text { case-control and } \\
4 \text { cohort studies } \\
(2,832,706 \mathrm{Cn} \text { and } 5,021 \mathrm{Cc})\end{array}$ & 2015 & A protective benefit in oral cancer \\
\hline $\mathrm{He}, 2020[81]$ & Oral & $\begin{array}{l}14 \text { case-control and } \\
5 \text { cohort studies }(6456 \mathrm{Cc})\end{array}$ & $\begin{array}{l}\text { September } \\
2018\end{array}$ & $\begin{array}{l}\text { High and intermediate versus } \\
\text { low coffee intake was associated } \\
\text { with a reduced risk of cancer. } \\
\text { Coffee intake might have } \\
\text { protective effects against cancer. }\end{array}$ \\
\hline Farvid, 2021 [82] & & $\begin{array}{l}2 \text { preoperative studies } \\
\qquad(8900 \mathrm{Cc})\end{array}$ & $\begin{array}{l}1980-2010 \\
1991-2011\end{array}$ & $\begin{array}{c}>3 \mathrm{c} / \mathrm{d} \text { of coffee was associated } \\
\text { with a } 25 \% \text { lower risk of cancer. } \\
\text { Among cancer survivors, } \\
\text { higher postdiagnostic coffee }\end{array}$ \\
\hline
\end{tabular}


TABle 3: Continued.

\begin{tabular}{|c|c|c|c|c|}
\hline First author, date & Type of cancer & Study group & $\begin{array}{l}\text { Date of } \\
\text { completion of } \\
\text { included data }\end{array}$ & Observed effect on coffee consumption \\
\hline & & & & $\begin{array}{c}\text { consumption was associated } \\
\text { with better cancer } \\
\text { and overall survival. }\end{array}$ \\
\hline Turati, 2011 [83] & \multirow{3}{*}{$\begin{array}{l}\text { Oral and } \\
\text { pharyngeal }\end{array}$} & $\begin{array}{l}1 \text { cohort and } 8 \text { case-control } \\
\text { studies }(2,633 \mathrm{Cc})\end{array}$ & October 2009 & $\begin{array}{c}\text { Coffee drinking is } \\
\text { inversely related to } \\
\text { oral pharyngeal cancer risk. }\end{array}$ \\
\hline Miranda, 2017 [84] & & $\begin{array}{l}13 \text { case-control and } \\
4 \text { cohort studies }\end{array}$ & August 2016 & $\begin{array}{c}\text { An inverse association } \\
\text { between high consumption } \\
\text { and the risk of } \\
\text { both cancer types }\end{array}$ \\
\hline Hildebrand, 2013 [85] & & $\begin{array}{l}\text { A prospective US cohort study } \\
(967,564 \mathrm{Cn} \text { and } 868 \mathrm{Cc})\end{array}$ & $1982-2008$ & $\begin{array}{c}\text { Intake of }>4 \mathrm{c} / \mathrm{d} \text { was } \\
\text { associated with a } 49 \% \text { lower } \\
\text { risk of cancer. Caffeinated coffee } \\
\text { intake was inversely associated } \\
\text { with oral/pharyngeal } \\
\text { cancer mortality. }\end{array}$ \\
\hline
\end{tabular}

Vaseghi, 2016 [86]

Nonmelanoma
skin

Caini, 2017 [87]
6 independent studies (320,370 Pt and 104,770 Cc) January 2016 skin 13 articles $(37,627 \mathrm{Cc})$ February 2016

Caffeinated coffee might have chemopreventive effects dose-dependent effects against basal cell carcinoma A moderate protective effect against basal cell cancer development

The risk of cancer decreased by $3 \%$ and $4 \%$ for

$1 \mathrm{c} / \mathrm{d}$ increment of total coffee and caffeinated coffee consumption, respectively.

Cutaneous melanoma

23 studies $(2,268,338 \mathrm{Pt})$

August 2015
2 case-control (846 Cc and 843

Liu, 2016 [89]

Caffeinated coffee might have chemopreventive effects against cancer.

$\mathrm{Cn})$ and 5 cohort studies
$(844,246 \mathrm{Pt}$ and 5,737 Cc)

9 studies $(927,173 \mathrm{Pt}$ and $3,787 \mathrm{Cc}$ )

Melanoma

Yew, 2016 [90]

Melanoma

Micek, 2018 [91]

7 studies $(1,418,779 \mathrm{Pt}$ and 9,211 Cc)

March 2017

\section{November 2015 \\ September 2015}


TABLE 3: Continued.

\begin{tabular}{|c|c|c|c|c|}
\hline First author, date & Type of cancer & Study group & $\begin{array}{c}\text { Date of } \\
\text { completion of } \\
\text { included data }\end{array}$ & Observed effect on coffee consumption \\
\hline Lukic, 2018 [94] & & $\begin{array}{c}12 \text { cohort and } 8 \text { case-control } \\
\text { studies }(11,663 \mathrm{Pt} \\
\text { and } 2,746 \mathrm{Cc})\end{array}$ & August 2016 & Protective effect \\
\hline
\end{tabular}

Bravi, 2013 [95]

Bai, 2016 [96]

Bravi, 2017 [97]

Kennedy, 2017 [54]

Discacciati, 2014 [98]

Lu, 2014 [99]

Cao, 2014 [100]

Zhong, 2014 [101]

Huang, 2014 [102]

Liu, 2015 [103]

Xia, 2017 [104]
8 cohort and 8 control studies $(3,153 \mathrm{Cc})$

11 studies $(340,749 \mathrm{Cn}$ and $2,795 \mathrm{Cc}$ )

August 2015

September 2012

18 cohorts $(2,272,642 \mathrm{Pt}$ and $2,905 \mathrm{Cc})$ and 8 casecontrol studies, $(4,652 \mathrm{Cn}$ and $1,825 \mathrm{Cc}$ )
The risk of cancer is reduced by

$40 \%$ for any coffee consumption

vs. no consumption regardless of the subjects' sex.

An inverse association between coffee consumption and cancer risk was observed, with quantitative evidence.

The meta-analysis provides a precise quantification of the inverse relation between coffee consumption and the risk of cancer.

An extra 2 cups of caffeinated and decaffeinated coffee were associated with reductions of 27 and

Uninformed $\quad 14 \%$ in the risk of cancer. Increased consumption is associated with a reduced risk of cancer, including preexisting liver disease.

Inversely associated with the risk of fatal cancer

High (highest $\geq 4$ or $5 \mathrm{c} / \mathrm{d}$ ) consumption may not

12 case-control $(9,461 \mathrm{Cn}$ and 7,909 Cc) and 9 cohort studies $(455,123 \mathrm{Pt})$

June 2013 only be associated with a reduced risk of cancer but also inversely associated with fatal and high-grade cancer.

10 cohort studies (206,096 and Pt8,973 Cc)

June 2013 Coffee consumption may decrease the risk of cancer.

An increase of $2 \mathrm{c} / \mathrm{d}$ was associated with a $7 \%$ decreased risk of cancer. A significant inverse relationship was also found for fatal cases and high-grade cancers.

A significant reverse association was found between highest versus none/lowest consumption and risk of cancer.

Coffee consumption may be associated with a reduced

13 cohort studies (539,577 Pt and 34,105 Cc)

Uninformed risk of cancer, and it also has an inverse association with nonadvanced cancer.

An effect on reducing the localized cancer risk 
TABLE 3: Continued.

\begin{tabular}{|c|c|c|c|c|}
\hline First author, date & Type of cancer & Study group & $\begin{array}{c}\text { Date of } \\
\text { completion of } \\
\text { included data }\end{array}$ & Observed effect on coffee consumption \\
\hline Pounis, 2017 [32] & & $\begin{array}{c}1 \text { cohort study } \\
(6,989 \mathrm{Pt} \text { and } 100 \mathrm{Cc})\end{array}$ & $\begin{array}{l}\text { March 2005- } \\
\text { April } 2010\end{array}$ & $\begin{array}{l}\text { Reduction of } 53 \% \text { lower cancer risk by } \\
\text { Italian-style coffee consumption }\end{array}$ \\
\hline Chen, 2021 [105] & & $\begin{array}{c}16 \text { cohort studies }(1.081 .586 \mathrm{Pt} \\
\text { and } 57,732 \mathrm{Cc})\end{array}$ & $\begin{array}{l}\text { September } \\
2020\end{array}$ & $\begin{array}{l}\text { Higher coffee consumption was } \\
\text { significantly associated with } \\
\text { a lower risk of cancer. }\end{array}$ \\
\hline
\end{tabular}

Zheng, 2013 [106]

Esophageal

Zhang, 2018 [107]

11 studies (457,010 Pt and $2,628 \mathrm{Cc})$

24 case-control and cohort studies $(7,376 \mathrm{Cc})$

October 2011

Borderline significantly inverse association of highest versus non/lowest consumption against risk (protective effects)

An inverse association between coffee consumption and incidence of cancer was found in East Asian participants.

Inverse association between Shafiei, 2019 [55] Ovarian 22 case-control and 20 studies

April 2018 decaffeinated coffee consumption and risk of cancer

Galeone, 2010 [108]

Li, 2013 [109]

Tian, 2013 [110]

Gan, 2017 [60]

Nakagawa-Senda, 2017 [111]
Colorectal

$$
24 \text { studies }(14,846 \mathrm{Cc})
$$

25 case-control $(15,522 \mathrm{Cc})$ and 16 cohort studies (10 443 Cc)

May 2010

May 2011$$
\text { (10 } 443 \text { Cc) }
$$

21 studies case-control and 12 cohort studies

Uninformed

19 cohort studies $(2,046,575 \mathrm{Pt}$ and 22,629 Cc)

August 2015

2 case-control studies (13,480 Cn and 2,696 Cc)

$1988-2000$ 2001-2005

Micek, 2019 [43]

Sartini, 2019 [56]
14 prospective studies (1,381,085 Pt and 28,404 Cc)

August 2018
Uninformed
A moderate favorable effect on cancer risk

Coffee consumption can significantly decrease the risks of colorectal and colon cancer, especially in Europe and for females.

A significant association was found between consumption and decreased risk of colorectal and colon cancer among subjects consuming $\geq 4 \mathrm{c} / \mathrm{d}$.

Coffee consumption was significantly associated with a decreased risk of cancer at $\geq 5 \mathrm{c} / \mathrm{d}$.

The study found a significant inverse linear trend between consumption and distal colon cancer and a tendency toward a lower risk of rectal cancer.

Restriction to decaffeinated coffee revealed a $15 \%$ lower risk of cancer for the highest category consumption. Coffee consumption was related with a decreased risk of cancer in a subgroup of never-smokers and in Asian countries.

Regarding colorectal cancer, a protective effect emerged in US subjects. Concerning colon cancer, a significant protective effect was noted only in European men and only in Asian women. Decaffeinated coffee exhibited a protective effect against colorectal cancer in men and women combined. 
TABLE 3: Continued.

\begin{tabular}{|c|c|c|}
\hline First author, date & Type of cancer & Study group \\
\hline Mackintosh, 2020 [57] & & $\begin{array}{l}1 \text { prospective observational } \\
\text { cohort study }(1171 \mathrm{Pt})\end{array}$ \\
\hline
\end{tabular}

Date of completion of Observed effect on coffee consumption included data

Increased consumption of coffee was associated with decreased risk of cancer progression. Significant
Um, $2020[58]$

Sang, 2013 [112]

Yu, 2016 [113]

Godos, 2017 [114]

Liver

Tamura, 2019 [115]

Tanaka, 2019 [116]

Bhurwal, 2020 [117]
1 prospective cohort study (107,061 Pt and 1,829 Cc)

1999-2015

$$
\begin{aligned}
& 9 \text { case-control and } \\
& 7 \text { cohort studies }
\end{aligned}
$$

20 cohort studies from

10 publications

13 studies

6 cohort studies from 5 publications

4 cohort and 4 case-control studies

20 prospective studies
September 2018

May 2012

Jan 2016

March 2017

Uninformed

June 2019 associations were noted for both caffeinated and decaffeinated coffee.

A higher intake of decaffeinated coffee was associated with a lower risk of colorectal, colon, and rectal cancer.

An inverse association was observed between coffee consumption and cancer.

A significant linear dose-response relationship was found between consumption and cancer risk.

An inverse correlation was noted between consumption and cancer. Increasing consumption by $1 \mathrm{c} / \mathrm{d}$ was associated with $15 \%$ reduction in cancer risk.

Consumption among Japanese people has a significant role in preventing cancer.

Coffee drinking decreases the risk of primary cancer among the Japanese population. Higher doses of coffee consumption were associated with a significant decrease in the risk of developing cancer.

A statistically significant protective effect of consumption and cancer risk was reported.

A suggestive inverse association was observed with greater consumption of coffee.

Dose-response meta-analysis showed that every $1 \mathrm{c} / \mathrm{d}$ of coffee decreases the risk of glioma by $3 \%$.

Inversely associated with cancer occurrence in a linear dose-response manner. The occurrence of cancer was reduced by $5 \%$ with each $1 \mathrm{c} / \mathrm{d}$ increment of coffee consumption.

A significant inverse association was observed between coffee consumption and the risk of cancer. 
TABLE 3: Continued.

\begin{tabular}{|c|c|c|c|c|}
\hline First author, date & Type of cancer & Study group & $\begin{array}{c}\text { Date of } \\
\text { completion of } \\
\text { included data }\end{array}$ & Observed effect on coffee consumption \\
\hline $\mathrm{Wu}, 2015$ [122] & & $\begin{array}{l}34 \text { case-control and } \\
6 \text { cohort studies }\end{array}$ & Uninformed & $\begin{array}{l}\text { An increased risk between coffee } \\
\text { consumption and cancer } \\
\text { was found. }\end{array}$ \\
\hline $\mathrm{Yu}, 2020[123]$ & & $\begin{array}{c}12 \text { cohort studies }(2601 \mathrm{Cc} \\
\text { and } 501,604 \mathrm{Pt})\end{array}$ & Uninformed & $\begin{array}{l}\text { Positive associations are } \\
\text { suggested between coffee } \\
\text { consumption and cancer } \\
\text { among male smokers } \\
\text { but not among never-smokers } \\
\text { and females. }\end{array}$ \\
\hline Dong, 2011 [124] & Pancreatic & $\begin{array}{c}14 \text { studies }(669,584 \mathrm{Pt} \\
\text { and } 1,496 \mathrm{Cc})\end{array}$ & August 2010 & $\begin{array}{l}\text { An inverse relationship was } \\
\text { found between coffee drinking } \\
\text { and the risk of cancer. }\end{array}$ \\
\hline Ran, 2016 [125] & & 20 cohort studies & June 2015 & $\begin{array}{l}\text { High coffee consumption is } \\
\text { associated with reduced risk. }\end{array}$ \\
\hline
\end{tabular}

Every 1-cup increase was

Nie, 2016 [126] $\quad 20$ articles $\quad \begin{gathered}\text { November } \\ 2015\end{gathered}$
associated with a $1 \%$ increase in risk. Coffee consumption may weakly increase the risk of cancer.

Li, 2019 [127]

13 cohort studies $(959,992$ $\mathrm{Pt}$ and 3,831 Cc)

9 cohort and 13 case-control

Xie, 2016 [128]

Gastric studies $(1,019,693 \mathrm{Cn}$ and $7,631 \mathrm{Cc})$

Shen, 2015 [129]

8 studies $(311,564 \mathrm{Pt}$ and $1,429 \mathrm{Cc}$ )

October 2013

February 2018

Coffee consumption is related to increased risk of cancer in a dose-response manner.

An increase in consumption was associated with a decreased risk of cancer.

Coffee consumption is associated with the development of cancer. More coffee drinking could result in an increased risk of cancer.

High coffee consumption

9 studies, 15 independent prospective cohorts

(1,289,314 Pt and 2,019 Cc)

February 2015

(>6.5 c/d) might increase the risk of cancer in the US population.

High coffee consumption is a risk factor for cancer.

\begin{tabular}{lcc} 
Deng, 2016 [131] & $\begin{array}{c}13 \text { cohort studies }(1,324,559 \mathrm{Pt} \\
\text { and 3,484 Cc) }\end{array}$ \\
\hline Chen, 2014 [132] & Laryngeal & $\begin{array}{c}10 \text { studies }(503,234 \mathrm{Cn} \\
\text { and 2,803 Cc) }\end{array}$ \\
\hline Kudwongsa, 2020 [133] & Lung & $\begin{array}{c}1 \text { prospective cohort study } \\
(12,668 \text { Pt and 138 Cc) }\end{array}$
\end{tabular}

September 2014

Coffee consumption would increase cancer risk.

Coffee consumption was associated with a reduced risk of cancer. Consumption may be a protective factor for cancer among this cohort.

5 prospective and 8 case-

Tang, 2010 [134] control studies (104,911 Pt and January 2009 $5347 \mathrm{Cc})$

Wang, 2012 [135]
9 publications $(3,008 \mathrm{Cc})$
Highest consumption was significantly associated with an increased risk of cancer.

A significantly positive association was found between coffee consumption and the risk of cancer. 
TABLE 3: Continued.

\begin{tabular}{|c|c|c|c|c|}
\hline First author, date & Type of cancer & Study group & $\begin{array}{c}\text { Date of } \\
\text { completion of } \\
\text { included data }\end{array}$ & Observed effect on coffee consumption \\
\hline Xie, 2016 [136] & & $\begin{array}{c}5 \text { cohort and } 12 \text { case-control } \\
\text { studies }(102,516 \mathrm{Cn} \\
\text { and } 12,276 \mathrm{Cc})\end{array}$ & March 2015 & $\begin{array}{l}\text { Cancer risk is significantly increased } \\
\text { by } 47 \% \text { in the population with } \\
\text { the highest category intake } \\
\text { of coffee compared with that } \\
\text { with the lowest category intake. }\end{array}$ \\
\hline Zhu, 2020 [137] & & $\begin{array}{l}17 \text { prospective cohort studies } \\
(1.1 \text { million } \mathrm{Pt} \text { and } 20,280 \mathrm{Cc})\end{array}$ & Uninformed & $\begin{array}{l}\text { Higher consumption of coffee is } \\
\text { associated with increased cancer risk. }\end{array}$ \\
\hline
\end{tabular}

pooled analyses to bypass the shortage of individual studies [10].

The database of human meta-analysis studies is more abundant today than ever before. Among them, there is a great diversity and due to contradictions between them or the limited scope of their conclusions, they are often not considered, or their interpretation is difficult. For this reason, in this review, we endeavored to make an exhaustive summary of meta-analysis studies (78 out of 115 published in PubMed until April 2021), which found a significant association (positive or negative) between coffee consumption and different types of cancer development, treatment, or advancement.

Table 3 shows meta-analyses, cohort, or prospective studies published between 2010 and 2021. Importantly, the large number of patients involved in these studies provides evidence on the effect of years of coffee consumption on humans. We collected and analyzed more than 75 studies (as shown in Table 3), the vast majority of which (63) reported beneficial effects of coffee consumption, such as less development, metastasis, or mortality from cancer of different origins.

Most publications showed a negative association between coffee consumption and the risk or development of different types of cancer (Table 3, italic rows); these include breast, oral, oral, and pharyngeal, melanoma, skin and skin nonmelanoma, prostate, colorectal, endometrial, liver, leukemic and hepatocellular carcinoma, brain, and thyroid cancer among others (18 cancer types). Instead, a dual association was observed in bladder, gastric, pancreatic, and lung cancer, although only a few publications demonstrated this association. Surprisingly, we found that only 12 publications showed positive associations between cancer and coffee consumption (bold rows), as observed in a few types of cancer, including lung, bladder, pancreatic, laryngeal, and gastric cancer.

Although caffeine has been shown to have anticancer activity both in vivo and in vitro, many epidemiological studies have published evidence indicating that the risk of cancer decreased even in people who ingested decaffeinated coffee $[43,52-58]$. In this sense, Hall et al. discovered that the amounts of many of the bioactive components, such as caffeic acid, chlorogenic acid, ferulic acid, pyrogallic acid, and trigonelline, did not change when decaffeinated coffee was compared to caffeinated coffee [59].
This update reveals a growing body of statistically significant evidence from epidemiological studies, suggesting that coffee drinking in most people (including different sexes, ethnicity, and ages) is beneficial and inversely associated with cancer risk $[6,60]$. The fact that we found few publications on the positive association of coffee consumption and cancer does not imply that it is less important but rather suggests that more research should be carried out, as this would make it possible to formulate a clearer hypothesis.

Undoubtedly, moderate coffee consumption of up to 4 cups/day can be enjoyed as part of a healthy, balanced diet and an active lifestyle [9], since health claims associated with its consumption are broad enough to recommend it as a protective beverage. Probing for the detrimental effects of coffee should be focused on further drawing a conclusive approach for end-users to eliminate the ambiguities [29].

Higher doses of coffee have higher benefits in terms of risk reduction. However, further biological and epidemiological studies are required to determine the exact mechanism and analyze the specific subgroups [61]. In addition, it is important to recommend caution to avoid the concomitant use of coffee with drugs that have a significant interaction with coffee. There should be an adequate time interval between the intake of drugs and coffee based on the properties of the drugs. Pharmacists and physicians must be aware of the potential risks of drug-coffee interaction and counsel patients appropriately. Further in vitro and in vivo studies should be performed on frequently prescribed drugs to obtain robust evidence of the pharmacokinetic interaction with coffee [62].

\section{Conclusions}

In the last decade of research, the overall view on the impact of coffee on health has shifted from mostly detrimental outcomes towards a beneficial profile. In fact, the data on cancer disease are mostly balanced towards beneficial effects. The subsequent production of more clinical data with a higher number of cases, together with a better understanding of the components of coffee, has contributed to changing this perspective. It can be concluded according to the current knowledge that the labeling of coffee as a mostly unhealthy beverage lacks scientific support.

Throughout this review, we have detailed the main components of coffee, their variation in the roasting process, and the bioactivity of many of them. We provide a wealth of up- 
to-date information on the existing experimental evidence for the anticarcinogenic effects of this beverage and a comprehensive review of the important significant evidence for these effects on humans. We have summarized the accumulating epidemiological evidence pointing towards a consistently inverse association between coffee consumption and the risk of breast, oral, pharyngeal, melanoma, endometrial, hepatocellular, prostate, colorectal, liver, and brain cancers, among others.

The prospects for new bioactive compounds and the development of new drugs are focused on natural products. Considering the wide range and depth of evidence already collected, coffee, a beverage that has been widely included in the human diet for years, could be used not only for its well-known taste and stimulant, pleasurable effects, but also for social, pharmaceutical, and clinical purposes, as it provides health benefits and significant effects on cancer treatments.

More research is needed to find the right dosage and balance between the beneficial health effects of coffee (such as anticancer and antioxidant activities) and those traditionally considered negative. However, many of the "harmful" effects noted in antiquity can be attributed to excessive consumption or specific compounds (such as caffeine), which can be regulated or even eliminated from the beverage, thus minimizing the associated risks, without necessarily affecting the important beneficial effects described by the numerous research studies included in this review.

\section{Data Availability}

The data used to support the findings of this study are available from the corresponding authors upon request.

\section{Conflicts of Interest}

The authors declare that they have no known competing financial interests or personal relationships that could influence the work reported in this paper.

\section{Authors' Contributions}

All authors contributed equally to this work. Ayelén D. Nigra performed the conceptualization and acquisition of data, methodology, validation, formal analysis, investigation, and writing of the original draft, writing and editing of the review, and final approval of the manuscript. Anderson Junger Teodoro performed the conceptualization and interpretation of data, investigation, methodology, resources, writing and editing of the review, supervision, project administration, funding acquisition, and final approval of the manuscript. German A. Gil performed the conceptualization and design of the study, formal analysis and interpretation of data, investigation, methodology, resources, writing of the original draft, writing and editing of the review, supervision, project administration, funding acquisition, and final approval of the manuscript.

\section{Acknowledgments}

We thank CIQUIBIC (CONICET), Depto de Quimica Biologica, Facultad de Ciencias Quimicas, Universidad Nacional de Córdoba, Córdoba, Argentina. This work was supported by the Ministerio de Ciencia, Tecnología e Innovación Productiva, Argentina (PICT 398 2016-0986), PIP-CONICET 2015, and SeCyT 2016 and 2018 to GG. This study was partially funded by the Coordenação de Aperfeiçoamento de Pessoal de Nível Superior-Brasil (CAPES)-Finance Code 001400 and Fundação de Amparo à Pesquisa do Estado do Rio de Janeiro-FAPERJ (225031). We acknowledge the excellent assistance provided by Ms. Maria Alejandra Scotti for English editing of the manuscript.

\section{References}

[1] A. Samoggia and B. Riedel, "Consumers' perceptions of coffee health benefits and motives for coffee consumption and purchasing," Nutrients, vol. 11, no. 3, 2019.

[2] S. K. Bøhn, R. Blomhoff, and I. Paur, "Coffee and cancer risk, epidemiological evidence, and molecular mechanisms," Molecular Nutrition \& Food Research, vol. 58, no. 5, pp. 915-930, 2014.

[3] C. Ciaramelli, A. Palmioli, and C. Airoldi, "Coffee variety, origin and extraction procedure: implications for coffee beneficial effects on human health," Food Chemistry, vol. 278, pp. 47-55, 2019.

[4] I. A. Ludwig, M. N. Clifford, M. E. Lean, H. Ashihara, and A. Crozier, "Coffee: biochemistry and potential impact on health," Food \& Function, vol. 5, no. 8, pp. 1695-1717, 2014.

[5] C. Q. da Silva, A. D. S. Fernandes, G. F. Teixeira et al., "Risk assessment of coffees of different qualities and degrees of roasting," Food Research International, vol. 141, 2021.

[6] G. de Mejia and M. V. Ramirez-Mares, "Impact of caffeine and coffee on our health," Trends in Endocrinology \& Metabolism, vol. 25, no. 10, pp. 489-492, 2014.

[7] G. Grosso, J. Godos, F. Galvano, and E. L. Giovannucci, "Coffee, caffeine, and health outcomes: an umbrella review," Annual Review of Nutrition, vol. 37, pp. 131-156, 2017.

[8] R. Poole, O. J. Kennedy, P. Roderick, J. A. Fallowfield, P. C. Hayes, and J. Parkes, "Coffee consumption and health: umbrella review of meta-analyses of multiple health outcomes," BMJ, vol. 359, 2017.

[9] K. Nieber, "The impact of coffee on health," Planta Medica, vol. 83, no. 16, pp. 1256-1263, 2017.

[10] A. Cano-Marquina, J. J. Tarín, and A. Cano, "The impact of coffee on health," Maturitas, vol. 75, no. 1, pp. 7-21, 2013.

[11] J. A. T. Pennington, "Food composition databases for bioactive food components," Journal of Food Composition and Analysis, vol. 15, no. 4, pp. 419-434, 2002.

[12] B. E. Mojica, L. E. Fong, D. Biju et al., "The impact of the roast levels of coffee extracts on their potential anticancer activities," Journal of Food Science, vol. 83, no. 4, pp. 1125-1130, 2018.

[13] A. Priftis, D. Stagos, K. Konstantinopoulos et al., "Comparison of antioxidant activity between green and roasted coffee beans using molecular methods," Molecular Medicine Reports, vol. 12, no. 5, pp. 7293-7302, 2015.

[14] P. Górnaś, K. Dwiecki, A. Siger, J. Tomaszewska-Gras, M. Michalak, and K. Polewski, "Contribution of phenolic 
acids isolated from green and roasted boiled-type coffee brews to total coffee antioxidant capacity," European Food Research and Technology, vol. 242, pp. 641-653, 2016.

[15] W. Han, M. Ming, and Y. Y. He, "Caffeine Promotes Ultraviolet B-induced Apoptosis in Human Keratinocytes without Complete DNA Repair," The Journal of Biological Chemistry, vol. 286, no. 26, pp. 22825-22832, 2011.

[16] B. Salehi, P. Lopez-Jornet, E. Pons-Fuster López et al., "Plant-derived bioactives in oral mucosal lesions: a key emphasis to curcumin, lycopene, Chamomile, Aloe vera, Green Tea and Coffee Properties," Biomolecules, vol. 9, no. 3, p. 106, 2019.

[17] S. Hall, B. Desbrow, S. Anoopkumar-Dukie et al., "A review of the bioactivity of coffee, caffeine and key coffee constituents on inflammatory responses linked to depression," Food Research International, vol. 76, Part 3, pp. 626-636, 2015.

[18] M. Amigo-Benavent, S. Wang, R. Mateos, B. Sarriá, and L. Bravo, "Antiproliferative and cytotoxic effects of green coffee and yerba mate extracts, their main hydroxycinnamic acids, methylxanthine and metabolites in different human cell lines," Food and Chemical Toxicology, vol. 106, Part A, pp. 125-138, 2017.

[19] D. Bauer, J. Abreu, N. Jordão, J. Rosa, O. Freitas-Silva, and A. Teodoro, "Effect of Roasting Levels and Drying Process of Coffea canephora on the Quality of Bioactive Compounds and Cytotoxicity," International Journal of Molecular Sciences, vol. 19, no. 11, p. 3407, 2018.

[20] Y. Ren, C. Wang, J. Xu, and S. Wang, "Cafestol and kahweol: a review on their bioactivities and pharmacological properties," International Journal of Molecular Sciences, vol. 20, no. 17, p. 4238, 2019.

[21] C. S. Lima, D. G. Spindola, A. Bechara et al., "Cafestol, a diterpene molecule found in coffee, induces leukemia cell death," Biomedicine \& Pharmacotherapy, vol. 92, pp. 1045-1054, 2017.

[22] E. Langner and W. Rzeski, "Biological properties of melanoidins: a review," International Journal of Food Properties, vol. 17, no. 2, pp. 344-353, 2014.

[23] T. M. T. Nguyen, E. J. Cho, Y. Song, C. H. Oh, R. Funada, and H. J. Bae, "Use of coffee flower as a novel resource for the production of bioactive compounds, melanoidins, and biosugars," Food Chemistry, vol. 299, 2019.

[24] F. Piacente, I. Caffa, and A. Nencioni, "Nicotinic acid: a case for a vitamin that moonlights for cancer?," Cell Cycle, vol. 16, no. 18, pp. 1635-1636, 2017.

[25] J. Li, J. Qu, Y. Shi et al., "Nicotinic acid inhibits glioma invasion by facilitating Snail1 degradation," Scientific Reports, vol. 7, no. 1, 2017.

[26] N. Sharma, M. P. Dobhal, Y. C. Joshi, and M. K. Chahar, "Flavonoids: a versatile source of anticancer drugs," Pharmacognosy Reviews, vol. 5, no. 9, pp. 1-12, 2011.

[27] A. N. Panche, A. D. Diwan, and S. R. Chandra, "Flavonoids: an overview," Journal of Nutritional Science, vol. 5, 2016.

[28] U. Boettler, N. Volz, G. Pahlke et al., "Coffees rich in chlorogenic acid or N-methylpyridinium induce chemopreventive phase II-enzymes via the Nrf2/ARE pathway in vitro and in vivo," Molecular Nutrition \& Food Research, vol. 55, no. 5, pp. 798-802, 2011.

[29] M. S. Butt and M. T. Sultan, "Coffee and its consumption: benefits and risks," Critical Reviews in Food Science and Nutrition, vol. 51, no. 4, pp. 363-373, 2011.
[30] A. D. Nigra, D. de Almeida Bauer Guimarães, C. G. Prucca, O. Freitas-Silva, A. J. Teodoro, and G. A. Gil, "Antitumor effects of freeze-dried Robusta coffee (Coffea canephora) extracts on breast cancer cell lines," Oxidative Medicine and Cellular Longevity, vol. 2021, Article ID 5572630, 16 pages, 2021.

[31] J. Montenegro, L. S. dos Santos, R. G. G. de Souza et al., "Bioactive compounds, antioxidant activity and antiproliferative effects in prostate cancer cells of green and roasted coffee extracts obtained by microwave-assisted extraction (MAE)," Food Research International, vol. 140, 2021.

[32] G. Pounis, C. Tabolacci, S. Costanzo et al., "Reduction by coffee consumption of prostate cancer risk: evidence from the Moli-sani cohort and cellular models," International Journal of Cancer, vol. 141, no. 1, pp. 72-82, 2017.

[33] D. N. Raba, D. R. Chambre, D. M. Copolovici, C. Moldovan, and L. O. Copolovici, "The influence of high-temperature heating on composition and thermo-oxidative stability of the oil extracted from Arabica coffee beans," PLoS One, vol. 13, no. 7, 2018.

[34] K. Król, M. Gantner, A. Tatarak, and E. Hallmann, “The content of polyphenols in cofee beans as roasting, origin and storage effect," European Food Research and Technology, vol. 246, pp. 33-39, 2020.

[35] T. Makino, K. Izumi, K. Hiratsuka et al., "Anti-proliferative and anti-migratory properties of coffee diterpenes kahweol acetate and cafestol in human renal cancer cells," Scientific Reports, vol. 11, no. 1, p. 675, 2021.

[36] C. Oleaga, C. J. Ciudad, V. Noé, and M. Izquierdo-Pulido, "Coffee polyphenols change the expression of STAT5B and ATF-2 modifying cyclin D1 levels in cancer cells," Oxidative Medicine and Cellular Longevity, vol. 2012, Article ID 390385, 17 pages, 2012.

[37] İ. Gülçin, "Antioxidant activity of food constituents: an overview," Archives of Toxicology, vol. 86, no. 3, pp. 345391, 2012.

[38] I. D. Nwachukwu and R. E. Aluko, "Structural and functional properties of food protein-derived antioxidant peptides," Journal of Food Biochemistry, vol. 43, no. 1, 2019.

[39] C. S. Yang, C. T. Ho, J. Zhang, X. Wan, K. Zhang, and J. Lim, "Antioxidants: differing meanings in food science and health science," Journal of Agricultural and Food Chemistry, vol. 66, no. 12, pp. 3063-3068, 2018.

[40] A. A. Nuhu, "Bioactive micronutrients in coffee: recent analytical approaches for characterization and quantification," ISRN Nutrition, vol. 2014, Article ID 384230, 13 pages, 2014.

[41] A. Jiménez-Zamora, S. Pastoriza, and J. A. Rufián-Henares, "Revalorization of coffee by-products. Prebiotic, antimicrobial and antioxidant properties," LWT - Food Science and Technology, vol. 61, no. 1, pp. 12-18, 2015.

[42] J. Wolska, K. Janda, K. Jakubczyk, M. Szymkowiak, D. Chlubek, and I. Gutowska, "Levels of antioxidant activity and fluoride content in coffee infusions of Arabica, Robusta and green coffee beans in according to their brewing methods," Biological Trace Element Research, vol. 179, no. 2, pp. 327-333, 2017.

[43] A. Micek, A. Gniadek, P. Kawalec, and T. Brzostek, "Coffee consumption and colorectal cancer risk: a dose-response meta-analysis on prospective cohort studies," International Journal of Food Sciences and Nutrition, vol. 70, no. 8, pp. 986-1006, 2019. 
[44] N. Liang and D. D. Kitts, "Antioxidant property of coffee components: assessment of methods that define mechanisms of action," Molecules, vol. 19, no. 11, pp. 19180-19208, 2014.

[45] J. Czachor, M. Miłek, S. Galiniak, K. Stępień, M. Dżugan, and M. Mołoń, "Coffee extends yeast chronological lifespan through antioxidant properties," International Journal of Molecular Sciences, vol. 21, no. 24, p. 9510, 2020.

[46] A. Masek, M. Latos-Brozio, J. Kałuzna-Czaplinska, A. Rosiak, and E. Chrzescijanska, "Antioxidant properties of green coffee extract," Forests, vol. 11, no. 5, p. 557, 2020.

[47] S. Jung, M. H. Kim, J. H. Park, Y. Jeong, and K. S. Ko, “Cellular antioxidant and anti-inflammatory effects of coffee extracts with different roasting levels," Journal of Medicinal Food, vol. 20, no. 6, pp. 626-635, 2017.

[48] A. Bobková, M. Hudáček, S. Jakabová et al., "The effect of roasting on the total polyphenols and antioxidant activity of coffee," Journal of Environmental Science and Health. Part. $B$, vol. 55, no. 5, pp. 495-500, 2020.

[49] M. A. Schouten, S. Tappi, S. Angeloni et al., "Acrylamide formation and antioxidant activity in coffee during roasting - a systematic study," Food Chemistry, vol. 343, 2021.

[50] E. Dybkowska, A. Sadowska, R. Rakowska, M. Dębowska, F. Świderski, and K. Świąder, "Assessing polyphenols content and antioxidant activity in coffee beans according to origin and the degree of roasting," Roczniki Państwowego Zakładu Higieny, vol. 68, no. 4, pp. 347-353, 2017.

[51] T. Ismail, S. Donati-Zeppa, S. Akhtar et al., "Coffee in cancer chemoprevention: an updated review," Expert Opinion on Drug Metabolism \& Toxicology, vol. 17, no. 1, pp. 69-85, 2021.

[52] E. C. Lowcock, M. Cotterchio, L. N. Anderson, B. A. Boucher, and A. el-Sohemy, "High coffee intake, but not caffeine, is associated with reduced estrogen receptor negative and postmenopausal breast cancer risk with no effect modification by CYP1A2 genotype," Nutrition and Cancer, vol. 65, no. 3, pp. 398-409, 2013.

[53] Q. Zhou, M.-L. Luo, H. Li, M. Li, and J.-G. Zhou, "Coffee consumption and risk of endometrial cancer: a dose-response meta-analysis of prospective cohort studies," Scientific Reports, vol. 5, 2015.

[54] O. J. Kennedy, P. Roderick, R. Buchanan, J. A. Fallowfield, P. C. Hayes, and J. Parkes, "Coffee, including caffeinated and decaffeinated coffee, and the risk of hepatocellular carcinoma: a systematic review and dose-response meta-analysis," BMJ Open, vol. 7, no. 5, p. e013739, 2017.

[55] F. Shafiei, A. Salari-Moghaddam, A. Milajerdi, B. Larijani, and A. Esmaillzadeh, "Coffee and caffeine intake and risk of ovarian cancer: a systematic review and meta-analysis," International Journal of Gynecological Cancer, vol. 29, no. 3, pp. 579-584, 2019.

[56] M. Sartini, N. Bragazzi, A. Spagnolo et al., "Coffee consumption and risk of colorectal cancer: a systematic review and meta-analysis of prospective studies," Nutrients, vol. 11, no. 3, p. 694, 2019.

[57] C. Mackintosh, C. Yuan, F. S. Ou et al., "Association of coffee intake with survival in patients with advanced or metastatic colorectal cancer," JAMA Oncology, vol. 6, no. 11, pp. 1713-1721, 2020.

[58] C. Y. Um, M. L. McCullough, M. A. Guinter, P. T. Campbell, E. J. Jacobs, and S. M. Gapstur, "Coffee consumption and risk of colorectal cancer in the Cancer Prevention
Study-II Nutrition Cohort," Cancer Epidemiology, vol. 67, p. 101730, 2020.

[59] S. Hall, J. W. Yuen, and G. D. Grant, "Bioactive constituents in caffeinated and decaffeinated coffee and their effect on the risk of Depression-A Comparative Constituent Analysis study," Beverages, vol. 4, no. 4, p. 79, 2018.

[60] Y. Gan, J. Wu, S. Zhang et al., "Association of coffee consumption with risk of colorectal cancer: a meta-analysis of prospective cohort studies," Oncotarget, vol. 8, no. 12, pp. 18699-18711, 2017.

[61] R. Pranata, A. Feraldho, M. A. Lim et al., "Coffee and tea consumption and the risk of glioma: a systematic review and dose-response Meta-analysis," The British Journal of Nutrition, pp. 1-9, 2021.

[62] A. Belayneh and F. Molla, "The effect of coffee on pharmacokinetic properties of drugs : a review," BioMed Research International, vol. 2020, Article ID 7909703, 11 pages, 2020.

[63] P. Divis, J. Porizka, and J. Krikala, "The effect of coffee beans roasting on its chemical composition," Potravinarstvo Slovak Journal of Food Sciences, vol. 13, pp. 344-350, 2019.

[64] F. Wei, K. Furihata, M. Koda, F. Hu, T. Miyakawa, and M. Tanokura, "Roasting process of coffee beans as studied by nuclear magnetic resonance: time course of changes in composition," Journal of Agricultural and Food Chemistry, vol. 60, no. 4, pp. 1005-1012, 2012.

[65] C. Ciaramelli, A. Palmioli, A. de Luigi et al., "NMR-driven identification of anti-amyloidogenic compounds in green and roasted coffee extracts," Food Chemistry, vol. 252, pp. 171-180, 2018.

[66] A. S. P. Moreira, F. M. Nunes, C. Simões et al., "Data on coffee composition and mass spectrometry analysis of mixtures of coffee related carbohydrates, phenolic compounds and peptides," Data in Brief, vol. 13, pp. 145-161, 2017.

[67] J. K. Moon, H. S. Yoo, and T. Shibamoto, "Role of roasting conditions in the level of chlorogenic acid content in coffee beans: correlation with coffee acidity," Journal of Agricultural and Food Chemistry, vol. 57, no. 12, pp. 5365-5369, 2009.

[68] V. Sridevi, P. Giridhar, and G. A. Ravishankar, "Evaluation of roasting and brewing effect on antinutritional diterpenescafestol and kahweol in coffee," Global Journal of Medical Research, vol. 11, 2011.

[69] K. Król, M. Gantner, A. Tatarak, and E. Hallmann, "The content of polyphenols in coffee beans as roasting, origin and storage effect," European Food Research and Technology, vol. 246, no. 1, pp. 33-39, 2020.

[70] A. Palmioli, C. Ciaramelli, R. Tisi et al., "Natural compounds in cancer prevention: effects of coffee extracts and their main polyphenolic component, 5-O-caffeoylquinic acid, on oncogenic Ras proteins," Chemistry, an Asian Journal, vol. 12, no. 18, pp. 2457-2466, 2017.

[71] M. Funakoshi-Tago, K. Tago, C. Li, S. Hokimoto, and H. Tamura, "Coffee decoction enhances tamoxifen proapoptotic activity on MCF-7 cells," Scientific Reports, vol. 10, no. 1, p. 19588, 2020.

[72] X. Yu, Z. Bao, J. Zou, and J. Dong, "Coffee consumption and risk of cancers: a meta-analysis of cohort studies," BMC Cancer, vol. 11, no. 1, 2011.

[73] X. J. Li, Z. J. Ren, J. W. Qin et al., "Coffee consumption and risk of breast cancer: an up-to-date meta-analysis," PLoS One, vol. 8, no. 1, 2013. 
[74] W. Jiang, Y. Wu, and X. Jiang, "Coffee and caffeine intake and breast cancer risk: an updated dose-response meta-analysis of 37 published studies," Gynecologic Oncology, vol. 129, no. 3, pp. 620-629, 2013.

[75] M. Simonsson, V. Söderlind, M. Henningson et al., "Coffee prevents early events in tamoxifen-treated breast cancer patients and modulates hormone receptor status," Cancer Causes \& Control, vol. 24, no. 5, pp. 929-940, 2013.

[76] A. H. Rosendahl, C. M. Perks, L. Zeng et al., "Caffeine and caffeic acid inhibit growth and modify estrogen receptor and insulin-like growth factor I receptor levels in human breast cancer," Clinical Cancer Research, vol. 21, no. 8, pp. 1877-1887, 2015.

[77] A. Lafranconi, A. Micek, P. de Paoli et al., "Coffee intake decreases risk of postmenopausal breast cancer: a doseresponse meta-analysis on prospective cohort studies," Nutrients, vol. 10, no. 2, p. 112, 2018.

[78] C. Sánchez-Quesada, A. Romanos-Nanclares, A. M. Navarro et al., "Coffee consumption and breast cancer risk in the SUN project," European Journal of Nutrition, vol. 59, no. 8, pp. 3461-3471, 2020.

[79] Y. Zhang, X. Wang, and D. Cui, “Association between coffee consumption and the risk of oral cancer: a meta-analysis of observational studies," International Journal of Clinical and Experimental Medicine, vol. 8, no. 7, pp. 11657-11665, 2015.

[80] Y. M. Li, J. Peng, and L. Z. Li, "Coffee consumption associated with reduced risk of oral cancer: a meta- analysis," Oral Surgery, Oral Medicine, Oral Pathology and Oral Radiology, vol. 121, no. 4, pp. 381-389.e1, 2016.

[81] T. He, X. Guo, X. Li, C. Liao, and W. Yin, "Association between coffee intake and the risk of oral cavity cancer: a meta-analysis of observational studies," European Journal of Cancer Prevention, vol. 29, no. 1, pp. 80-88, 2020.

[82] M. S. Farvid, N. D. Spence, B. A. Rosner, W. C. Willett, A. H. Eliassen, and M. D. Holmes, "Post-diagnostic coffee and tea consumption and breast cancer survival," British Journal of Cancer, vol. 124, no. 11, pp. 1873-1881, 2021.

[83] F. Turati, C. Galeone, C. la Vecchia, W. Garavello, and A. Tavani, "Coffee and cancers of the upper digestive and respiratory tracts: meta- analyses of observational studies," Annals of Oncology, vol. 22, no. 3, pp. 536-544, 2011.

[84] J. Miranda, L. Monteiro, R. Albuquerque et al., "Coffee is protective against oral and pharyngeal cancer: a systematic review and meta-analysis," Medicina Oral, Patología Oral y Cirugía Bucal, vol. 22, no. 5, pp. e554-e561, 2017.

[85] J. S. Hildebrand, A. V. Patel, M. L. McCullough et al., "Coffee, tea, and fatal oral/pharyngeal cancer in a large prospective US cohort," American Journal of Epidemiology, vol. 177, no. 1, pp. 50-58, 2013.

[86] G. Vaseghi, S. Haghjoo-Javanmard, J. Naderi, A. Eshraghi, M. Mahdavi, and M. Mansourian, "Coffee consumption and risk of nonmelanoma skin cancer: a dose-response metaanalysis," European Journal of Cancer Prevention, vol. 27, no. 2, pp. 164-170, 2018.

[87] S. Caini, S. Cattaruzza, B. Bendinelli et al., "Coffee, tea and caffeine intake and the risk of non-melanoma skin cancer: a review of the literature and meta-analysis," European Journal of Nutrition, vol. 56, no. 1, 2017.

[88] J. Wang, X. Li, and D. Zhang, "Coffee consumption and the risk of cutaneous melanoma: a meta-analysis," European Journal of Nutrition, vol. 55, no. 4, pp. 1317-1329, 2016.
[89] J. Liu, B. Shen, M. Shi, and J. Cai, "Higher caffeinated coffee intake is associated with reduced malignant melanoma risk: a meta-analysis study," PLoS One, vol. 11, no. 1, 2016.

[90] Y. W. Yew, Y. C. Lai, and R. A. Schwartz, "Coffee consumption and melanoma: a systematic review and meta-analysis of observational studies," American Journal of Clinical Dermatology, vol. 17, no. 2, pp. 113-123, 2016.

[91] A. Micek, J. Godos, A. Lafranconi, M. Marranzano, and A. Pajak, "Caffeinated and decaffeinated coffee consumption and melanoma risk: a dose-response meta-analysis of prospective cohort studies," International Journal of Food Sciences and Nutrition, vol. 69, no. 4, pp. 417-426, 2018.

[92] Y. Je and E. Giovannucci, "Coffee consumption and risk of endometrial cancer: findings from a large up-to-date metaanalysis," International Journal of Cancer, vol. 131, no. 7, pp. 1700-1710, 2012.

[93] A. Lafranconi, A. Micek, F. Galvano et al., "Coffee decreases the risk of endometrial cancer: a dose-response metaanalysis of prospective cohort studies," Nutrients, vol. 9, no. 11, 2017.

[94] M. Lukic, N. Guha, I. Licaj et al., "Coffee drinking and the risk of endometrial cancer: an updated meta-analysis of observational studies," Nutrition and Cancer, vol. 70, no. 4, pp. 513-528, 2018.

[95] F. Bravi, C. Bosetti, A. Tavani, S. Gallus, and C. la Vecchia, "Coffee reduces risk for hepatocellular carcinoma: an updated meta-analysis," Clinical Gastroenterology and Hepatology, vol. 11, no. 11, pp. 1413-1421.e1, 2013.

[96] K. Bai, Q. Cai, Y. Jiang, and L. Lv, "Coffee consumption and risk of hepatocellular carcinoma: a meta-analysis of eleven epidemiological studies," Oncotargets and Therapy, vol. 9, pp. 4369-4375, 2016.

[97] F. Bravi, A. Tavani, C. Bosetti, P. Boffetta, and C. La Vecchia, "Coffee and the risk of hepatocellular carcinoma and chronic liver disease: a systematic review and meta-analysis of prospective studies," European Journal of Cancer Prevention, vol. 26, no. 5, pp. 368-377, 2017.

[98] A. Discacciati, N. Orsini, and A. Wolk, "Coffee consumption and risk of nonaggressive, aggressive and fatal prostate cancer-a dose-response meta-analysis," Annals of Oncology, vol. 25, no. 3, pp. 584-591, 2014.

[99] Y. Lu, L. Zhai, J. Zeng et al., "Coffee consumption and prostate cancer risk: an updated meta-analysis," Cancer Causes \& Control, vol. 25, no. 5, pp. 591-604, 2014.

[100] S. Cao, L. Liu, X. Yin, Y. Wang, J. Liu, and Z. Lu, "Coffee consumption and risk of prostate cancer: a meta-analysis of prospective cohort studies," Carcinogenesis, vol. 35, no. 2, pp. 256-261, 2014.

[101] S. Zhong, W. Chen, X. Yu, Z. Chen, Q. Hu, and J. Zhao, "Coffee consumption and risk of prostate cancer: an up-to-date meta-analysis," European Journal of Clinical Nutrition, vol. 68, no. 3, pp. 330-337, 2014.

[102] T. B. Huang, Z. F. Guo, X. L. Zhang et al., "Coffee consumption and urologic cancer risk: a meta-analysis of cohort studies," International Urology and Nephrology, vol. 46, no. 8, pp. 1481-1493, 2014.

[103] H. Liu, G. H. Hu, X. C. Wang et al., "Coffee consumption and prostate cancer risk: a meta-analysis of cohort studies," Nutrition and Cancer, vol. 67, no. 3, pp. 392-400, 2015.

[104] J. Xia, J. Chen, J. X. Xue, J. Yang, and Z. J. Wang, “An upto-date meta-analysis of coffee consumption and risk of 
prostate cancer," Urology Journal, vol. 14, no. 5, pp. 40794088, 2017.

[105] X. Chen, Y. Zhao, Z. Tao, and K. Wang, "Coffee consumption and risk of prostate cancer: a systematic review and metaanalysis," BMJ Open, vol. 11, no. 2, 2021.

[106] J. S. Zheng, J. Yang, Y. Q. Fu, T. Huang, Y. J. Huang, and D. Li, "Effects of green tea, black tea, and coffee consumption on the risk of esophageal cancer: a systematic review and meta-analysis of observational studies," Nutrition and Cancer, vol. 65, no. 1, pp. 1-16, 2013.

[107] J. Zhang, B. Zhou, and C. Hao, "Coffee consumption and risk of esophageal cancer incidence," Medicine, vol. 97, no. 17, p. e0514, 2018.

[108] C. Galeone, F. Turati, C. la Vecchia, and A. Tavani, "Coffee consumption and risk of colorectal cancer: a meta-analysis of case-control studies," Cancer Causes \& Control, vol. 21, no. 11, pp. 1949-1959, 2010.

[109] G. Li, D. Ma, Y. Zhang, W. Zheng, and P. Wang, "Coffee consumption and risk of colorectal cancer: a meta-analysis of observational studies," Public Health Nutrition, vol. 16, no. 2, pp. 346-357, 2013.

[110] C. Tian, W. Wang, Z. Hong, and X. Zhang, "Coffee consumption and risk of colorectal cancer: a dose-response analysis of observational studies," Cancer Causes \& Control, vol. 24, no. 6, pp. 1265-1268, 2013.

[111] H. Nakagawa-Senda, H. Ito, S. Hosono, I. Oze, H. Tanaka, and K. Matsuo, "Coffee consumption and the risk of colorectal cancer by anatomical subsite in Japan: results from the HERPACC studies," International Journal of Cancer, vol. 141, no. 2, pp. 298-308, 2017.

[112] L. X. Sang, B. Chang, X. H. Li, and M. Jiang, "Consumption of coffee associated with reduced risk of liver cancer: a metaanalysis," BMC Gastroenterology, vol. 13, no. 1, 2013.

[113] C. Yu, Q. Cao, P. Chen et al., "An updated dose-response meta-analysis of coffee consumption and liver cancer risk," Scientific Reports, vol. 6, no. 1, 2016.

[114] J. Godos, A. Micek, M. Marranzano, F. Salomone, D. Rio, and S. Ray, "Coffee consumption and risk of biliary tract cancers and liver cancer: a dose-response meta-analysis of prospective cohort studies," Nutrients, vol. 9, no. 9, p. 950, 2017.

[115] T. Tamura, A. Hishida, and K. Wakai, "Coffee consumption and liver cancer risk in Japan: a meta-analysis of six prospective cohort studies," Nagoya Journal of Medical Science, vol. 81, no. 1, pp. 143-150, 2019.

[116] K. Tanaka, A. Tamakoshi, Y. Sugawara et al., "Coffee, green tea and liver cancer risk: an evaluation based on a systematic review of epidemiologic evidence among the Japanese population," Japanese Journal of Clinical Oncology, vol. 49, no. 10, pp. 972-984, 2019.

[117] A. Bhurwal, P. Rattan, S. Yoshitake et al., "Inverse association of coffee with liver cancer development: an updated systematic review and meta-analysis," Journal of Gastrointestinal and Liver Diseases, vol. 29, no. 3, pp. 421-428, 2020.

[118] Y. Song, Z. Wang, Y. Jin, and J. Guo, “Association between tea and coffee consumption and brain cancer risk: an updated meta-analysis," World Journal of Surgical Oncology, vol. 17, no. 1, p. 51, 2019.

[119] J. H. Creed, S. A. Smith-Warner, T. A. Gerke, and K. M. Egan, "A prospective study of coffee and tea consumption and the risk of glioma in the UK Biobank," European Journal of Cancer, vol. 129, pp. 123-131, 2020.
[120] C. C. Shao, D. Luo, G. D. Pang et al., "A dose-response metaanalysis of coffee consumption and thyroid cancer occurrence," International Journal of Food Sciences and Nutrition, vol. 71, no. 2, pp. 176-185, 2020.

[121] K. Sugiyama, Y. Sugawara, Y. Tomata, Y. Nishino, A. Fukao, and I. Tsuji, "The association between coffee consumption and bladder cancer incidence in a pooled analysis of the Miyagi Cohort Study and Ohsaki Cohort Study," European Journal of Cancer Prevention, vol. 26, no. 2, pp. 125-130, 2017.

[122] W. Wu, Y. Tong, Q. Zhao, G. Yu, X. Wei, and Q. Lu, "Coffee consumption and bladder cancer: a meta-analysis of observational studies," Scientific Reports, vol. 5, no. 1, 2015.

[123] E. Y. W. Yu, Y. Dai, A. Wesselius et al., "Coffee consumption and risk of bladder cancer: a pooled analysis of 501,604 participants from 12 cohort studies in the BLadder Cancer Epidemiology and Nutritional Determinants (BLEND) international study," European Journal of Epidemiology, vol. 35, no. 6, pp. 523-535, 2020.

[124] J. Dong, J. Zou, and X. F. Yu, "Coffee drinking and pancreatic cancer risk: a meta-analysis of cohort studies," World Journal of Gastroenterology, vol. 17, no. 9, pp. 1204-1210, 2011.

[125] H. Q. Ran, J. Z. Wang, and C. Q. Sun, "Coffee consumption and pancreatic cancer risk: an update meta-analysis of cohort studies," Pakistan Journal of Medical Sciences, vol. 32, no. 1, pp. 253-259, 1969.

[126] K. Nie, Z. Xing, W. Huang, W. Wang, and W. Liu, "Coffee intake and risk of pancreatic cancer: an updated metaanalysis of prospective studies," Minerva Medica, vol. 107, no. 4, pp. 270-278, 2016.

[127] T. D. Li, H. W. Yang, P. Wang et al., "Coffee consumption and risk of pancreatic cancer: a systematic review and doseresponse meta-analysis," International Journal of Food Sciences and Nutrition, vol. 70, no. 5, pp. 519-529, 2019.

[128] Y. Xie, S. Huang, T. He, and Y. Su, "Coffee consumption and risk of gastric cancer: an updated meta-analysis," Asia Pacific Journal of Clinical Nutrition, vol. 25, no. 3, pp. 578-588, 2016.

[129] Z. Shen, H. Liu, and H. Cao, "Coffee consumption and risk of gastric cancer: an updated meta-analysis," Clinics and Research in Hepatology and Gastroenterology, vol. 39, no. 2, pp. 245-253, 2015.

[130] S. B. Zeng, H. Weng, M. Zhou, X. L. Duan, X. F. Shen, and $\mathrm{X}$. T. Zeng, "Long-term coffee consumption and risk of gastric cancer: a PRISMA-compliant dose-response metaanalysis of prospective cohort studies," Medicine (Baltimore), vol. 94, no. 38, 2015.

[131] W. Deng, H. Yang, J. Wang et al., "Coffee consumption and the risk of incident gastric cancer-a meta-analysis of prospective cohort studies," Nutrition and Cancer, vol. 68, no. 1, pp. 40-47, 2016.

[132] J. Chen and S. Long, "Tea and coffee consumption and risk of laryngeal cancer: a systematic review meta-analysis," PLOS One, vol. 9, no. 12, 2014.

[133] W. Kudwongsa, S. Promthet, K. Suwanrungruang, A. Phunmanee, and P. Vatanasapt, "Coffee consumption and lung cancer risk: a prospective cohort study in Khon Kaen Thailand," Asian Pacific Journal of Cancer Prevention, vol. 21, no. 8, pp. 2367-2371, 2020.

[134] N. Tang, Y. Wu, J. Ma, B. Wang, and R. Yu, "Coffee consumption and risk of lung cancer: a meta-analysis," Lung Cancer, vol. 67, no. 1, pp. 17-22, 2010. 
[135] Y. Wang, X. Yu, Y. Wu, and D. Zhang, "Coffee and tea consumption and risk of lung cancer: a dose-response analysis of observational studies," Lung Cancer, vol. 78, no. 2, pp. 169-170, 2012.

[136] Y. Xie, J. Qin, G. Nan, S. Huang, Z. Wang, and Y. Su, “Coffee consumption and the risk of lung cancer: an updated metaanalysis of epidemiological studies," European Journal of Clinical Nutrition, vol. 70, no. 2, pp. 199-206, 2016.

[137] J. Zhu, S. A. Smith-Warner, D. Yu et al., "Associations of coffee and tea consumption with lung cancer risk," International Journal of Cancer, vol. 148, 2021. 